D 1110

\title{
ウェーブレット変換による移動体検出の振動解析への応用
}

\section{Application of moving body detection by wavelet transform to the vibration analysis}

\author{
Masaki YAMAGISHI
}

\begin{abstract}
In order to know the oscillating mode in amplitude, the image processing technique was used. In that technique, two sequential images were derivate to detect the oscillating body. Oscillating mode image is then obtained by synthesizing these derivation images. In this detection, wavelet transform was tried to apply for many sequential images. In this study, Daubechies N2 wavelet was used for four sequential images. From the result, the synthesizing image by using wavelet transform show more clear oscillating mode than that by using derivation in the part of rapid moving.

Keywords: Wavelet transform, Moving body detection, Vibration analysis
\end{abstract}

\section{1. 緒 論}

流体振動利用方式風水力発電学目指し，振㲜体として 多関節平板を考案した．流体の運動エネルギを効梁よく 振動エネルギに変換する形状を設計するためには，その 振動特性を明らかにする必要がある。これまで実験 '及 び数值シミュレーション ${ }^{2}$ によりその特性を調査してき た．振動特性として振動モード（変位形態）が举げられ る，運動する物体の変位量の計測には光学式センサが良 く用いられるが，多関節平板は変位量が大きいため，従 来の光学式センサでは計測が不可能であった，そこで振 動する様子を動画像や連続写真加ら捉えることを試みた。 これまでは連続する2枚の画像から, 差分により振動体 を抽出し，複数枚の抽出結果を重社合わせることで振動 モード画像を合成した：この抽出操作においてウェーブ レット変換を利用することにより，より多くの画像列か ら動領域を探查・抽出することができ，より精密な画像 が作製できるものと考えた．本研究の目的は，ウェーブ レット変換により画像列から動領域を抽出し, 差分によ る方法と比較・考察することである.

\section{2. 多関節平板}

流体振動を発生させる振動体として考案した，多関節 平板の概略を図1に示す. 多関節平板は，旗の構造を単 純化させたモデルで，支持軸を含めた複数軸で連結され た平板群を言う。本研究で用いた多関節平板は，3軸 3 枚平板で構成されており，3枚とも同一形状である．平 板 1 枚の形状は流れ方向長さ $l$, スパン方向長さ $b$ とす る長方形である、多關節平板は，厚さ $0.08 \mathrm{~mm}$ のポリエ チレン製シートを厚さ $0.5 \mathrm{~mm}$ のプラスチック板で挟む
模造となっている，プレート間には $1 \mathrm{~mm} の$ 隙間を設け ており，この隙間でのポリェチレン製シートの曲げが， 軸回転に相当寸る.

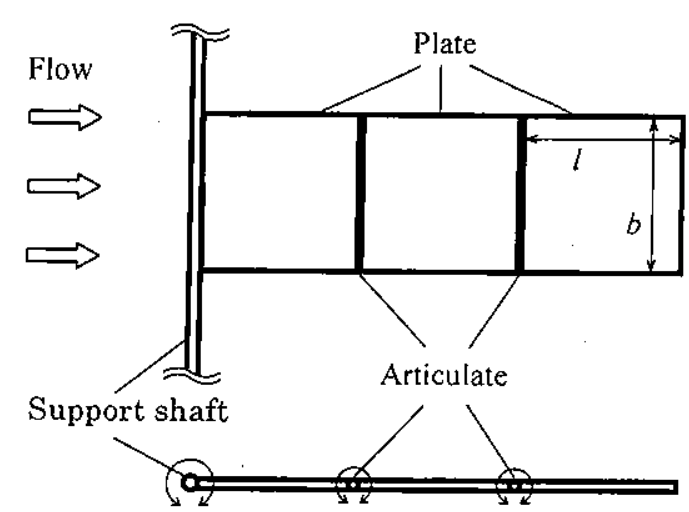

Fig.1 Multi-articulated flat plate

\section{3. 実験及び解析}

\section{1 実験装置及び方法}

実験は，吹出し口断面積 $400 \mathrm{~mm} \times 400 \mathrm{~mm}$ の吹出し式風 洞を用いて行っだ〉.多関節平板は，2枚の平行なアク リル製端板により支持されている，多関節平板が一様流 中で振動している様子を、デジタルカメラ（Casio, EX-F1）を用いて連続写真を撮影した。シャッター間隔 は1/60sで，60枚の写真を撮影した。 今回用いた多関節平

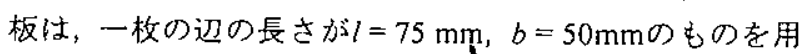
い, 流速 $U_{0}=5.0 \mathrm{~m} / \mathrm{s}$ での振䖝の様子を撮影した。 


\section{2 画像処理}

動画像や連続写真のように，連続した画像列を時間方 向の画像フレームとする，画像面上の座標を固定し，そ の座標における画素值を時間方向に追跡すると，一つの 時系列信号が得られる. 各座標についてこの操作を行う と，画像サイズの数だけ時系列信号が得られることとな る

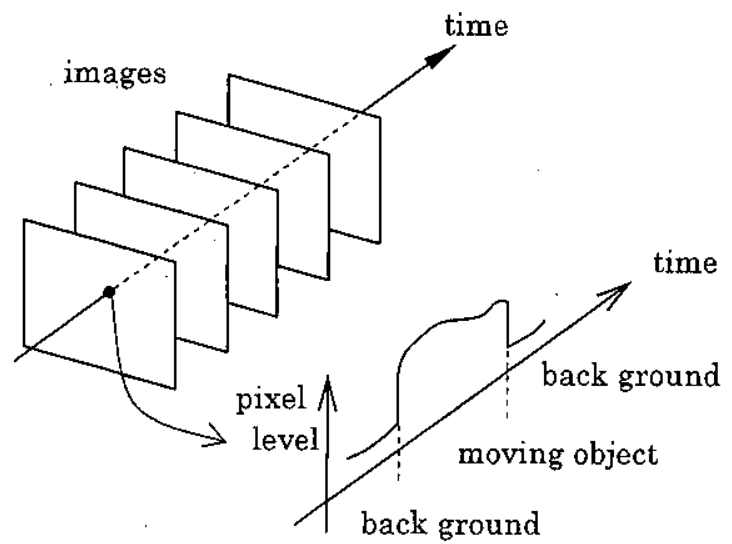

Fig.2 Sequential images and time-dependent signal of pixel level

固定されたカメラによって撮影された動画像，または 連続写真において，上述の時系列信号の変化から移動体 の通過を知ることができる，図 2 に示すようにある座 標に拈ける画素値が一定の值を保っているとき，その時 間带はその場所が背景領域にあることを意味する。一方 画素值が変動しているとき，その時間帯ではその座標が 動領域であると考えられる。

そこでこの時系列信号の変化を，ウェーブレット変換 により検出する．今回，Daubechies N2 ウェーブレットを 使用した，サポート長が 4 であるため，高周波成分を得 るためには 4 つ画像フレームが必要となる，前述の差 分による抽出方法は，いわば Haarのウェーブレットを用 いた方法に当たる。 ウェーブレット変換後，低周波成分 を削除して高周波成分のみを用いて逆変換することによ り，振動物体を抽出する，さらに抽出画像を合成するこ とで，振動モード画像を構成した，今回使用したカメラ は最大で 60 枚の連続写真が撮影できるため, 32 枚の連 続写真を解析に用いた。

\section{4. 結果及び考察}

差分により得られた合成画像を Fig.3に，ウェーブレ ット変換を用いた合成画像を Fig.4 に示す，今回用いた 多関節平板は流速 $U_{0}=5.0 \mathrm{~m} / \mathrm{s}$ において，第 2 平板で節 のある振動を示した。これらの図を比較すると，平板の 振動速度が速い部分で違いが見られる。差分で得られた 画像では，速度の速い部分では平板が不鮮明であるが，

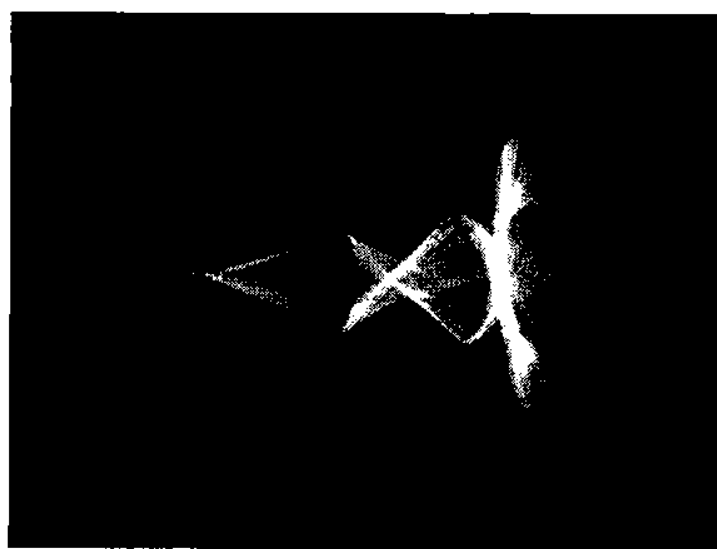

Fig.3 Synthesized image of oscillating mode by using derivation method

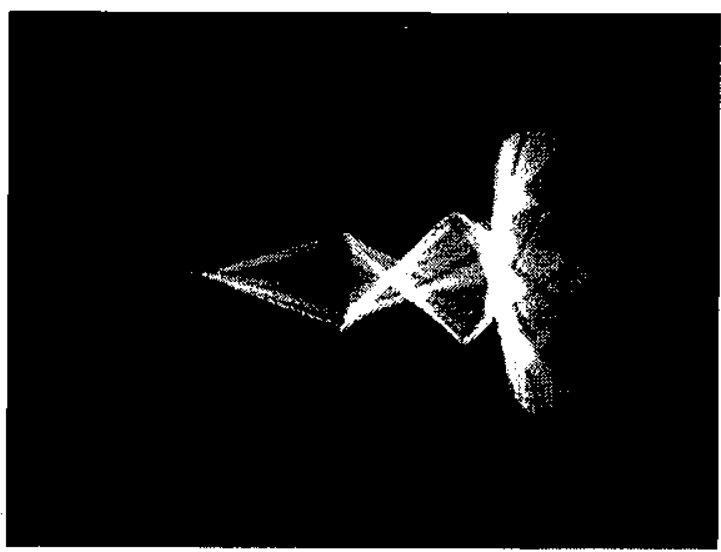

Fig.4 Synthesized image of oscillating mode by using wavelet transform

ウェーブレット変換を用いた手法では，他の部分に比べ 濃度が薄いものの抽出がなされている。

5. 結論

ウェーブレット変換を用いた移動体検出の方法を振動 体のモード解析に応用した，その結果，差分合成による 方法に比べ，変位速度が速い部分においてより明瞭な検 出が行われた。

\section{参 考 文 献}

1）前田龍，山岸真幸: 多関節平板の一様流中にお方打振動特 性、日本機械学会北陸信越学生会第 36 回学生員卒業研究 発表满演会, 2007.

2）山岸真幸: 数值解析による多関節平板周りの渦棒造に関す る研究，日本流体力学会年会 2008 講演要旨集, pp.47, 2008.

3) 新帛耕一: ウェーブレット画像解析,科学技術出版, 2000.

4) 新井康平: 独習ウェーブレット解析, 近代科学社， 2006 .

5) 新井承平, 瀬戸要:ウェーブレット解析による移動物体の動 的特性識別手法，可視化情報学会誌，24,Suppl.1,2004 